\title{
Improved yield of a-L-arabinofuranosidase by newly isolated Aspergillus niger ADH-11 and synergistic effect of crude enzyme on saccharification of maize stover
}

\author{
Harshvadan Patel ${ }^{1}$, Digantkumar Chapla ${ }^{2}$, Jyoti Divecha ${ }^{3}$ and Amita Shah ${ }^{1 *}$
}

\begin{abstract}
Background: In the view of depleting resources and ever-increasing price of crude oil, there is an urge for the development of alternative sources to solve the issue of fuel in the coming years. Lignocellulosic biomass is considered to be the most potential alternative resources for fossil fuel. Bioconversion of cellulosic and hemicellulosic components into fermentable sugars is the key step in producing fuel ethanol from lignocellulose. The enzymatic hydrolysis of lignocellulosic biomass needs a highly balanced composition of cellulases and hemicellulases. Commercial enzymes are usually poor in accessory hemicellulolytic enzymes like a-L-arabinofuranosidase. The addition of such accessory enzymes in combination with cellulase or hemicellulase plays a vital role in improving the total yield of fuel ethanol by enhancing the saccharification yield.

Results: The newly isolated fungal strain Aspergillus niger ADH-11 produced a maximum of $22.14 \mathrm{U} / \mathrm{g}$ of a-L-arabinofuranosidase under solid-state fermentation using wheat bran as the substrate and modified Mandels-Weber medium at $30^{\circ} \mathrm{C}$ after $180 \mathrm{~h}$ of incubation. The optimization of various fermentation parameters was performed by response surface methodology employing Plackett-Burman design followed by Box-Behnken design. The yield of a-L-arabinofuranosidase was enhanced by 2.34-fold after executing statistical optimization of various fermentative parameters. Crude a-L-arabinofuranosidase was found to be highly stable for $3 \mathrm{~h}$ at its optimum temperature $\left(55^{\circ} \mathrm{C}\right)$ and $\mathrm{pH}(4.0)$. The assessment of the crude enzyme extract in saccharification of alkali-treated maize stover revealed that the supplementation of crude $\mathrm{a}$-L-arabinofuranosidase to commercial cellulase and crude xylanase mixture increased the saccharification yield up to $730 \mathrm{mg} / \mathrm{g}$ of maize stover.

Conclusions: The newly isolated A. niger ADH-11 was found to be a potential producer of a-L-arabinofuranosidase. The crude enzyme was active at low pH and high temperature which makes it suitable for various industrial applications such as enzymatic saccharification of lignocellulosic biomass. The supplementation of a-L-arabinofuranosidase enzyme to commercial cellulases and hemicellulases improves the bioconversion of lignocellulosic biomass to a greater extent.
\end{abstract}

Keywords: Aspergillus niger ADH-11; a-L-Arabinofuranosidase; Solid-state fermentation; Response surface methodology; Maize stover

\footnotetext{
* Correspondence: arshah02@yahoo.com

${ }^{1}$ BRD School of Biosciences, Sardar Patel Maidan Satellite Campus, Sardar Patel University, PO Box No. 39, Vallabh Vidyanagar 388120, Gujarat, India Full list of author information is available at the end of the article
} 


\section{Background}

Hemicelluloses are the second most abundant renewable source on the earth after celluloses representing up to 30 to $35 \%$ of the total dry weight of the carbohydrate polymers, out of which xylan is the major constituent $[1,2]$. Xylan-rich agroindustrial wastes are among the most important biomass sources in the world, representing an annual generation of 40 million tons causing considerable damage to economic activities in the agroindustrial sector and environment as well [3]. As xylan is the complex structure, its complete degradation requires the action of accessory hemicellulolytic enzymes out of which $\alpha$ - $\mathrm{L}$-arabinofuranosidase is one of the most important enzymes $[2,4]$.

$\alpha$-L-Arabinofuranosidase is an exo-type enzyme that generally catalyzes the cleavage of the terminal $\alpha-\mathrm{L}$ arabinofuranosyl residues of arabinoxylan, arabinan, and arabinogalactan present in the hemicellulose structure. The arabinose side chains on hemicelluloses participate in cross-linking within the plant cell wall structure. L-Arabinose substitutions on xylan strongly inhibit the action of xylan-degrading enzymes, thus preventing the complete degradation of the polymer to its basic xylose units [5]. It is now well established that the action of $\alpha$-L-arabinofuranosidase alone or in the combination with other hemicellulolytic enzymes is inevitable for enzymatic bioconversion of lignocellulosic biomass in to sugars which can be further fermented to ethanol. This enzyme is also finds a wide range of applications in food, feed, paper pulp, and pharmaceutical industries.

The production of $\alpha$-L-arabinofuranosidase is widespread among bacteria and fungi. However, filamentous fungi are more attractive than bacteria as potential producers of these enzymes as fungi secrete higher enzyme levels in the culture medium than bacteria [6]. $\alpha$-L-Arabinofuranosidase production has been reported by many fungal strains, such as Trichoderma reseei (142 nkat/mg), Aspergillus awamori (22.0 U/mg), Aspergillus nidulans (30.0 mIU/ml), Aspergillus terreus (6.0 nkat/ml), Penicillium purpurogenum (1.0 U/ml), Aspergillus oryzae (0.02 U/mg), and Penicillium chrysogenum $(0.34 \mathrm{U} / \mathrm{mg})$ [7-13].

Solid-state fermentation (SSF) is a microbial process in which solid material is used as the substrate which may provide necessary nutrients and serves as an anchorage for the cell. SSF can be of special interest in those processes where the crude fermented product may be used directly as the enzyme source [14]. Fungi grow well on moist substrates in the absence of free-flowing water [15] and produce large amount of extracellular enzymes like cellulases, hemicellulases, and ligninases. The production of enzymes using fungi under SSF is many a times higher than submerged fermentation (SmF), since SSF processes reproduce the natural living conditions of such fungi [16]. The use of SSF for production of enzymes has many economic advantages over SmF like no need for complex and sophisticated machinery, easy product recovery, simple and inexpensive substrate for the fermentation, low energy demand, high volumetric productivity, and often a high yield of product [17]. Response surface methodology has been extensively used in optimizing various fermentative parameters for enzyme production using solid-state fermentation [18-21].

Considering the potential and future prospects of $\alpha$-L-arabinofuranosidase, the present study was aimed at production of $\alpha$-L-arabinofuranosidase under SSF by a newly isolated fungal strain of Aspergillus niger ADH-11 employing response surface methodology. The properties of crude $\alpha$-L-arabinofuranosidase were also evaluated to predict its end application, and the crude enzyme was supplemented to cocktails containing cellulase and xylanase to check synergistic action during saccharification of maize stover.

\section{Methods \\ Materials}

All the reagents, media, and chemicals used under study were of analytical grade purchased from Qualigens Fine Chemicals Pvt Ltd, HiMedia Laboratories Pvt Ltd, Merck \& Co., and Loba Chemie Pvt Ltd from Mumbai, Maharashtra, India. $p$-Nitrophenyl- $\alpha$-L-arabinofuranoside was obtained from Sigma-Aldrich, St. Louis, MO, USA. Wheat straw, rice straw, corn cobs, and maize bran were provided by a local farmer, whereas wheat bran and rice bran were procured from local market. The raw materials were washed thoroughly with water, dried at $80^{\circ} \mathrm{C}$, and stored at room temperature in air tight plastic bags until use. The commercial cellulase used in this study was provided by MAPs Enzyme Limited (Ahmedabad, Gujarat, India).

\section{Microbial strain}

The $\alpha$-L-arabinofuranosidase-producing fungal strain was isolated from decaying custard apple and it was identified as A. niger $\mathrm{ADH}-11$ by the Agharkar Research Institute (ARI) Pune, India on the basis of its molecular characteristics. The sequence of the strain was submitted to NCBI gene bank with accession no. KF026012. The culture was grown on potato dextrose agar (PDA) slant and store at $4^{\circ} \mathrm{C}$. It was subcultured every 15 days.

\section{a-L-Arabinofuranosidase production under SSF using different agro residues by $A$. niger ADH-11}

The $\alpha$-L-arabinofuranosidase production was carried out in 250-ml Erlenmeyer flasks containing $5 \mathrm{~g}$ of washed dried agro residues (wheat bran, wheat straw, rice bran, rice straw, corn cobs, and maize bran) moistened with $10 \mathrm{ml}$ of modified Mandels-Weber medium containing the following (g/l): urea, 0.3; ammonium sulfate, 1.4; $\mathrm{KH}_{2} \mathrm{PO}_{4}, 0.3 ; \mathrm{CaCl}_{2}, 0.3 ; \mathrm{MgSO}_{4} .7 \mathrm{H}_{2} \mathrm{O}, 0.3$; proteose 
peptone. 1.0 and (mg/l) $\mathrm{MnSO}_{4} \cdot 7 \mathrm{H}_{2} \mathrm{O} .1 .6 ; \mathrm{ZnSO}_{4} .7 \mathrm{H}_{2} \mathrm{O}$, 1.4; $\mathrm{CoCl}_{2}, 2$; Tween 80, 0.1\%; and initial $\mathrm{pH}$ 5.3. The medium and the substrate were sterilized separately at $121^{\circ} \mathrm{C}$ for $15 \mathrm{~min}$ at $15 \mathrm{lbs}$. The inoculum was prepared using 7 days old $A$. niger ADH-11 slants. The spore suspension was prepared by adding $5 \mathrm{ml}$ of $1 \%$ Tween 80 to each slant. The spore count was carried out using Neuber's chamber. The medium and the substrate were mixed at the time of inoculation at $10^{8}$ spore $/ \mathrm{ml}$ and incubated at $30^{\circ} \mathrm{C}$ under static condition. The contents of the flasks were mixed intermittently (twice a day), and the crude enzyme was extracted from each flask at regular interval of time (at every $24 \mathrm{~h}$ ).

\section{Enzyme extraction}

The contents from each flask were extracted using a minimum quantity $(30 \mathrm{ml})$ of $50 \mathrm{mM}$ sodium citrate buffer ( $\mathrm{pH} 5.3$ ) along with $0.2 \mathrm{ml}$ of Tween 80. The flasks were kept at $30^{\circ} \mathrm{C}$ with $150 \mathrm{rpm}$ for $30 \mathrm{~min}$ for thorough mixing of the contents, followed by filtration through a wet muslin cloth with thorough squeezing, and the filtrate was centrifuged at $8,000 \mathrm{rpm}$ for $30 \mathrm{~min}$. The clear supernatant thus obtained was used as a crude enzyme for further studies.

\section{Enzyme assays}

The $\alpha$-L-arabinofuranosidase activity was determined according to the method reported by Yanai and Sato [22] with some modifications. The reaction mixture consisting of $1 \mathrm{mM} p$-nitrophenyl- $\alpha$-L-arabinofuranoside in $50 \mathrm{mM}$ sodium citrate buffer $(\mathrm{pH}$ 5.3) was incubated with enzyme at $50^{\circ} \mathrm{C}$ for $10 \mathrm{~min}$ in total volume of $0.5 \mathrm{ml}$. The reaction was terminated by adding $1 \mathrm{ml}$ of $2 \mathrm{M}$ sodium carbonate solution. The amount of $p$-nitrophenol released was determined by measuring absorbance at $410 \mathrm{~nm}$. One unit of $\alpha$-L-arabinofuranosidase activity is defined as amount of enzyme required to release $1 \mu \mathrm{mol}$ of $p$-nitrophenol per minute under assay condition. The xylanase activity was measured using 1\% birch wood xylan solution as reported earlier [23]. The substrate was prepared in $50 \mathrm{mM}$ sodium citrate buffer of $\mathrm{pH} 5.3$. The enzyme reaction was carried out at $50^{\circ} \mathrm{C}$ for $10 \mathrm{~min}$. After incubation, the reaction was terminated by adding $1 \mathrm{ml}$ of DNS reagent. The enzyme activity was determined by measuring the release of reducing sugar using xylose as standard [24]. One unit of xylanase activity is defined as the amount of enzyme releasing $1 \mu \mathrm{mol}$ of xylose per minute under assay condition. The filter paper activity was measured according to IUPAC recommendation employing filter paper (Whatman no. 1) as a substrate [25]. The release of reducing sugars in $60 \mathrm{~min}$ at $55^{\circ} \mathrm{C}$ and $\mathrm{pH} 4.8$ (50 mM sodium citrate buffer) was measured as glucose equivalent using DNS method. One unit of filter paper activity is defined as amount of enzyme releasing $1 \mu \mathrm{mol}$ of glucose per minute under assay condition.

\section{Protein estimation}

The soluble protein was estimated by Folin's method using bovine serum albumin as a standard [26].

\section{Optimization of $a$-L-arabinofuranosidase production using response surface methodology}

The optimization of the physicochemical parameters for $\alpha$-L-arabinofuranosidase production was performed in two stages. Initially, ten variables were considered for screening using Plakett-Burman design (PBD) to identify the variables, which significantly influenced $\alpha$-L-arabinofuranosidase production, and in the second stage the significant variables screened from PBD were further optimized using a Box-Behnken design (BBD).

\section{Screening of parameters affecting a-L-arabinofuranosidase production by $P B D$}

In this study, urea, ammonium sulfate, proteose peptone, yeast extract, $\mathrm{KH}_{2} \mathrm{PO}_{4}, \mathrm{CaCl}_{2}, \mathrm{MgSO}_{4}, \mathrm{pH}$, moisture ratio, and fermentation time were selected as the independent variables. Each variable was set at two levels, higher and lower (Table 1). The experimental design is given in Table 2. The significance of regression coefficients was tested by $T$ test for $\alpha$-L-arabinofuranosidase production (Table 3).

\section{Optimization of significant parameters for $a-L-$ arabinofuranosidase production by $B B D$}

BBD involves full factorial search by observing simultaneous, systematic, and efficient variation of important components on the fermentation process. Urea, $\mathrm{MgSO}_{4}$, $\mathrm{CaCl}_{2}, \mathrm{pH}$, ammonium sulfate, and fermentation time were selected as individual variable for the production of $\alpha$-L-arabinofuranosidase. BBD in six factors having three center runs (with a total of 54 experimental runs) was

Table 1 Actual and coded level of variables tested with Plakett-Burman design

\begin{tabular}{|c|c|c|c|}
\hline & Code & -1 & 1 \\
\hline Urea & $\mathrm{X} 1$ & 0.1 & 5 \\
\hline $\mathrm{MgSO}_{4}$ & $\times 2$ & 0.1 & 3 \\
\hline $\mathrm{CaCl}_{2}$ & X3 & 0.1 & 3 \\
\hline $\mathrm{pH}$ & $X 4$ & 3 & 8 \\
\hline Ammonium sulfate & $\times 5$ & 1 & 10 \\
\hline Fermentation time & X6 & 48 & 216 \\
\hline Protease peptone & X7 & 1 & 5 \\
\hline Yeast extract & X8 & 1 & 5 \\
\hline $\mathrm{KH}_{2} \mathrm{PO}_{4}$ & X9 & 0.1 & 3 \\
\hline Moisture ratio & $\times 10$ & $1: 1$ & $1: 3$ \\
\hline
\end{tabular}


Table 2 PBD matrix for the screening of variables influencing $a$-L-arabinofuranosidase production

\begin{tabular}{llllllllllll}
\hline Run & $\mathbf{X} \mathbf{1}$ & $\mathbf{X 2}$ & $\mathbf{X 3}$ & $\mathbf{X 4}$ & $\mathbf{X 5}$ & $\mathbf{X 5}$ & $\mathbf{X 7}$ & $\mathbf{X 8}$ & $\mathbf{X 9}$ & $\mathbf{X 1 0}$ & $\mathbf{a - L - A r a b i n o f u r a n o s i d a s e ~ ( U / g ) ~}$ \\
\hline 1 & 0.1 & 0.1 & 0.1 & 3 & 1 & 48 & 1 & 1 & 0.1 & 1 & 8.75 \\
2 & 5 & 0.1 & 0.1 & 8 & 10 & 216 & 1 & 5 & 0.1 & 3 & 35.41 \\
3 & 5 & 0.1 & 3 & 3 & 1 & 216 & 5 & 5 & 0.1 & 1 & 35.01 \\
4 & 0.1 & 3 & 3 & 3 & 10 & 48 & 5 & 5 & 0.1 & 3 & 9.4 \\
5 & 0.1 & 3 & 3 & 8 & 1 & 48 & 1 & 5 & 3 & 3 & 4.97 \\
6 & 5 & 0.1 & 0.1 & 3 & 10 & 48 & 1 & 5 & 3 & 1 & 12.35 \\
7 & 0.1 & 3 & 3 & 8 & 10 & 216 & 1 & 1 & 0.1 & 1 & 19.85 \\
8 & 0.1 & 0.1 & 0.1 & 8 & 1 & 216 & 5 & 5 & 3 & 1 & 35.08 \\
9 & 0.1 & 0.1 & 0.1 & 3 & 10 & 216 & 5 & 1 & 3 & 3 & 30.41 \\
10 & 5 & 3 & 3 & 3 & 1 & 216 & 1 & 1 & 3 & 3 & 32.15 \\
11 & 5 & 3 & 3 & 8 & 10 & 48 & 5 & 1 & 3 & 1 & 10.79 \\
12 & 5 & 0.1 & 0.1 & 8 & 1 & 48 & 5 & 1 & 0.1 & 3 & 11.81
\end{tabular}

used for the optimization of $\alpha$-L-arabinofuranosidase production.

The design allowed to evaluate the main and interactive effects of urea (X1), $\mathrm{MgSO}_{4}$ (X2), $\mathrm{CaCl}_{2}$ (X3), $\mathrm{pH}$ (X4), ammonium sulfate (X5), and fermentation time (X6) for $\alpha$-L-arabinofuranosidase yield (U/g). The $\alpha-\mathrm{L}$ arabinofuranosidase yield $(\mathrm{U} / \mathrm{g})$ corresponding to the combined effects of six variables was studied in their specific range as shown in Table 4. The temperature was kept constant at $30^{\circ} \mathrm{C}$ throughout the experiment. All flasks were analyzed for $\alpha$-L-arabinofuranosidase yield at specific time intervals as planned in BBD. The plan of BBD in the coded levels of six independent variables is shown in Table 5.

For statistical calculation the independent variables were coded as follows:

Table 3 Regression coefficient for $\mathbf{a}$-L-arabinofuranosidase production

\begin{tabular}{lrrcrr}
\hline Term & Effect & Coefficient & $\begin{array}{l}\text { Standard error } \\
\text { Coefficient }\end{array}$ & $\boldsymbol{T}$ value & $\boldsymbol{P}$ value \\
\hline Constant & & 26.02 & 1.579 & 16.48 & 0.039 \\
Urea & 15.88 & 7.94 & 1.579 & 5.03 & 0.025 \\
$\begin{array}{l}\text { Ammonium } \\
\text { sulfate }\end{array}$ & -12.63 & -6.32 & 1.579 & -4.00 & 0.050 \\
$\begin{array}{l}\text { Protease } \\
\text { peptone }\end{array}$ & 4.21 & 2.10 & 1.579 & 1.33 & 0.410 \\
Yeast extract & 4.12 & 2.06 & 1.579 & 1.30 & 0.417 \\
$\mathrm{KH}_{2} \mathrm{PO}_{4}$ & -0.12 & -0.06 & 1.579 & -0.04 & 0.059 \\
$\mathrm{CaCl}_{2}$ & -28.81 & -14.40 & 4.737 & -3.04 & 0.002 \\
$\mathrm{MgSO}_{4}$ & 36.24 & 18.12 & 5.470 & 3.31 & 0.047 \\
$\mathrm{pH}$ & -12.73 & -6.37 & 1.579 & -4.03 & 0.050 \\
$\begin{array}{l}\text { Moisture } \\
\text { Ratio }\end{array}$ & -0.65 & -0.33 & 1.579 & -0.21 & 0.870 \\
$\begin{array}{l}\text { Fermentation } \\
\text { time }\end{array}$ & 32.68 & 16.34 & 1.579 & 10.35 & 0.047 \\
\hline
\end{tabular}

$$
x_{i}=\left(X_{i}-X_{\mathrm{o}}\right) / \delta X_{i}
$$

Where $X_{i}$ is the experimental value of the variable; $X_{\mathrm{o}}$ is the midpoint of $X_{i}, \delta X_{i}$ is the step change in $X_{i}$, and $x_{i}$ is the coded value for $X_{i}, i=1-6$.

The $\alpha$-L-arabinofuranosidase yield was fitted using response surface methodology applying Equation 2 and was analyzed using MINITAB 16.0 version:

$$
Y=\beta_{\mathrm{o}}+\beta_{i} x_{i}+\sum \beta_{\mathrm{ii}} x_{i}^{2}+\sum \beta_{i j} x_{i} x_{i}
$$

where $Y$ is the predicted response variable, $\beta_{\mathrm{o}}, \beta_{i}, \beta_{i i}, \beta_{i j}$ are fixed regression coefficients of the model, $x_{i}, x_{j}(i=1$, $2,3,4,5$ and $6, i \neq j, i<j=1,2,3,4,5,6)$ represent independent variables in the form of original values.

\section{Interpretation and data analysis}

The results of the experimental design were analyzed and interpreted using Minitab 16 (Minitab Inc, State College, PA, USA) statistical software. The prediction of fermentation parameters and generation of response contour plot by the model were also done by the same software. Analysis of variance (ANOVA) was used to establish the significance of the model parameters.

Table 4 Actual and coded level of variables tested with Box-Behnken design for $a-L-a r a b i n o f u r a n o s i d a s e$ production

\begin{tabular}{llll}
\hline Process variable & \multicolumn{3}{l}{ Coded level of variable } \\
\cline { 2 - 4 } & $\mathbf{- 1}$ & $\mathbf{0}$ & $\mathbf{+ 1}$ \\
\hline Urea (X1) & 0.1 & 2.55 & 5 \\
$\mathrm{MgSO}_{4}(\mathrm{X} 2)$ & 0.1 & 1.55 & 3 \\
$\mathrm{CaCl}_{2}(\mathrm{X} 3)$ & 0.1 & 1.55 & 3 \\
$\mathrm{pH}(\mathrm{X} 4)$ & 3 & 5.5 & 8 \\
Ammonium sulfate (X5) & 1 & 5.5 & 10 \\
Fermentation time (X6) & 48 & 132 & 216 \\
\hline
\end{tabular}


Table 5 Full factorial BBD matrix for a-L-arabinofuranosidase production by Aspergillus niger ADH-11

\begin{tabular}{|c|c|c|c|c|c|c|c|c|}
\hline \multirow[b]{2}{*}{ Run } & \multirow{2}{*}{$\begin{array}{l}\text { Urea } \\
\mathrm{X} 1\end{array}$} & \multirow{2}{*}{$\begin{array}{c}\mathrm{MgSO}_{4} \\
\mathrm{X} 2\end{array}$} & \multirow{2}{*}{$\begin{array}{c}\mathrm{CaCl}_{2} \\
\times 3\end{array}$} & \multirow{2}{*}{$\begin{array}{l}\mathrm{pH} \\
\mathrm{x} 4\end{array}$} & \multirow{2}{*}{$\begin{array}{l}\text { Ammonium sulfate } \\
\qquad 55\end{array}$} & \multirow{2}{*}{$\begin{array}{l}\text { Fermentation time } \\
\qquad 66\end{array}$} & \multicolumn{2}{|l|}{ a-L-Arabinofuranosidase } \\
\hline & & & & & & & Predicted activity $(\mathrm{U} / \mathrm{g})$ & Experimental activity $(\mathrm{U} / \mathrm{g})$ \\
\hline 1 & -1 & -1 & 0 & -1 & 0 & 0 & 24.803 & 23.750 \\
\hline 2 & 1 & -1 & 0 & -1 & 0 & 0 & 23.506 & 21.940 \\
\hline 3 & -1 & 1 & 0 & -1 & 0 & 0 & 21.359 & 24.070 \\
\hline 4 & 1 & 1 & 0 & -1 & 0 & 0 & 22.517 & 20.990 \\
\hline 5 & -1 & -1 & 0 & 1 & 0 & 0 & 21.465 & 22.510 \\
\hline 6 & 1 & -1 & 0 & 1 & 0 & 0 & 22.089 & 19.860 \\
\hline 7 & -1 & 1 & 0 & 1 & 0 & 0 & 20.756 & 21.840 \\
\hline 8 & 1 & 1 & 0 & 1 & 0 & 0 & 23.835 & 25.370 \\
\hline 9 & 0 & -1 & -1 & 0 & -1 & 0 & 18.686 & 20.850 \\
\hline 10 & 0 & 1 & -1 & 0 & -1 & 0 & 18.814 & 20.140 \\
\hline 11 & 0 & -1 & 1 & 0 & -1 & 0 & 19.025 & 19.720 \\
\hline 12 & 0 & 1 & 1 & 0 & -1 & 0 & 14.183 & 12.240 \\
\hline 13 & 0 & -1 & -1 & 0 & 1 & 0 & 16.684 & 17.410 \\
\hline 14 & 0 & 1 & -1 & 0 & 1 & 0 & 19.828 & 20.350 \\
\hline 15 & 0 & -1 & 1 & 0 & 1 & 0 & 21.293 & 18.750 \\
\hline 16 & 0 & 1 & 1 & 0 & 1 & 0 & 19.467 & 18.520 \\
\hline 17 & 0 & 0 & -1 & -1 & 0 & -1 & 20.493 & 17.850 \\
\hline 18 & 0 & 0 & 1 & -1 & 0 & -1 & 17.673 & 19.390 \\
\hline 19 & 0 & 0 & -1 & 1 & 0 & -1 & 12.448 & 13.680 \\
\hline 20 & 0 & 0 & 1 & 1 & 0 & -1 & 16.328 & 15.430 \\
\hline 21 & 0 & 0 & -1 & -1 & 0 & 1 & 22.543 & 23.930 \\
\hline 22 & 0 & 0 & 1 & -1 & 0 & 1 & 18.641 & 16.920 \\
\hline 23 & 0 & 0 & -1 & 1 & 0 & 1 & 21.868 & 20.640 \\
\hline 24 & 0 & 0 & 1 & 1 & 0 & 1 & 24.666 & 26.820 \\
\hline 25 & -1 & 0 & 0 & -1 & -1 & 0 & 16.175 & 16.160 \\
\hline 26 & 1 & 0 & 0 & -1 & -1 & 0 & 17.414 & 17.340 \\
\hline 27 & -1 & 0 & 0 & 1 & -1 & 0 & 14.703 & 12.370 \\
\hline 28 & 1 & 0 & 0 & 1 & -1 & 0 & 17.861 & 17.410 \\
\hline 29 & -1 & 0 & 0 & -1 & 1 & 0 & 19.621 & 19.590 \\
\hline 30 & 1 & 0 & 0 & -1 & 1 & 0 & 18.245 & 21.060 \\
\hline 31 & -1 & 0 & 0 & 1 & 1 & 0 & 17.154 & 17.710 \\
\hline 32 & 1 & 0 & 0 & 1 & 1 & 0 & 17.697 & 17.230 \\
\hline 33 & 0 & -1 & 0 & 0 & -1 & -1 & 15.256 & 15.060 \\
\hline 34 & 0 & 1 & 0 & 0 & -1 & -1 & 15.484 & 14.150 \\
\hline 35 & 0 & -1 & 0 & 0 & 1 & -1 & 15.089 & 14.820 \\
\hline 36 & 0 & 1 & 0 & 0 & 1 & -1 & 18.333 & 16.440 \\
\hline 37 & 0 & -1 & 0 & 0 & -1 & 1 & 22.735 & 23.410 \\
\hline 38 & 0 & 1 & 0 & 0 & -1 & 1 & 17.793 & 19.280 \\
\hline 39 & 0 & -1 & 0 & 0 & 1 & 1 & 23.168 & 25.720 \\
\hline 40 & 0 & 1 & 0 & 0 & 1 & 1 & 21.242 & 20.220 \\
\hline 41 & -1 & 0 & -1 & 0 & 0 & -1 & 16.569 & 15.160 \\
\hline 42 & 1 & 0 & -1 & 0 & 0 & -1 & 16.174 & 18.470 \\
\hline 43 & -1 & 0 & 1 & 0 & 0 & -1 & 13.391 & 15.960 \\
\hline
\end{tabular}


Table 5 Full factorial BBD matrix for a-L-arabinofuranosidase production by Aspergillus niger ADH-11 (Continued)

\begin{tabular}{rrrrlllll}
\hline 44 & 1 & 0 & 1 & 0 & 0 & -1 & 20.412 & 21.240 \\
45 & -1 & 0 & -1 & 0 & 0 & 1 & 24.726 & 23.410 \\
46 & 1 & 0 & -1 & 0 & 0 & 1 & 19.487 & 16.430 \\
47 & -1 & 0 & 1 & 0 & 0 & 1 & 20.467 & 18.660 \\
48 & 1 & 0 & 1 & 0 & 0 & 1 & 22.643 & 24.540 \\
49 & 0 & 0 & 0 & 0 & 0 & 0 & 18.998 & 16.630 \\
50 & 0 & 0 & 0 & 0 & 0 & 0 & 18.998 & 20.180 \\
51 & 0 & 0 & 0 & 0 & 0 & 0 & 18.998 & 17.460 \\
52 & 0 & 0 & 0 & 0 & 0 & 0 & 18.998 & 18.670 \\
54 & 0 & 0 & 0 & 0 & 0 & 0 & 18.998 & 19.560 \\
\hline
\end{tabular}

Wheat bran was used as the substrate at $30^{\circ} \mathrm{C}$ under SSF.

Effect of temperature and $\mathrm{pH}$ on $\mathrm{a}$-L-arabinofuranosidase activity

The optimum temperature for $\alpha$-L-arabinofuranosidase was determined by assaying relative activity at different temperatures ranging from $40^{\circ} \mathrm{C}$ to $75^{\circ} \mathrm{C}$. The optimum $\mathrm{pH}$ for $\alpha$-L-arabinofuranosidase was determined by assaying relative activity at different $\mathrm{pH}$ (3 to 7) using $50 \mathrm{mM}$ sodium citrate buffer for $\mathrm{pH} 3,4,5$, and $50 \mathrm{mM}$ sodium phosphate buffer for $\mathrm{pH} 6$ and 7.

\section{Temperature and $\mathrm{pH}$ stability of $\mathrm{a}$-L-arabinofuranosidase}

To determine the thermal stability of $\alpha$-L-arabinofuranosidase, the enzyme solution was treated at different temperatures $\left(45^{\circ} \mathrm{C}, 55^{\circ} \mathrm{C}\right.$, and $\left.65^{\circ} \mathrm{C}\right)$ in $50 \mathrm{mM}$ sodium citrate buffer $(\mathrm{pH} 4.0)$ in a temperature-controlled water bath and the residual activity was measured at different time intervals (60 min) up to $3 \mathrm{~h}$. To determine the $\mathrm{pH}$ stability of $\alpha-\mathrm{L}-$ arabinofuranosidase, the enzyme solution was appropriately diluted at different $\mathrm{pH}$ buffers (4, 5, 6 and 7) and left to room temperature and the residual activity was measured at different time intervals $(60 \mathrm{~min})$ up to $3 \mathrm{~h}$.

\section{Pretreatments of maize stover}

The substrate (maize stover) was washed, dried, and sieved to get uniform particle size before its use. The maize stover was given two separate pretreatments. In one case, pretreatment was given by preparing $15 \%$ slurry of maize stover in $4 \% \mathrm{NaOH}$ solution and was incubated at $30^{\circ} \mathrm{C}$ for $12 \mathrm{~h}$. The second pretreatment was given by $15 \%$ ammonia solution in the ratio of $(1: 4.5(w / v))$ to prepare the slurry. The slurry was autoclaved at $121^{\circ} \mathrm{C}$ and $15 \mathrm{lbs}$ for $1 \mathrm{~h}$. The substrate was washed completely with distilled water until neutral and dried in oven at $80^{\circ} \mathrm{C}$ until moisture was evaporated.

\section{Enzymatic hydrolysis of maize stover}

The enzymatic saccharification of pretreated and untreated maize stover was carried out using crude $\alpha-\mathrm{L}$ - arabinofuranosidase from $A$. niger ADH-11, crude xylanase from Aspergillus foetidus MTCC 4898 [18], and commercial cellulase individually. The crude enzyme from A. niger ADH-11, crude enzyme from $A$. foetidus MTCC 4898, and commercial cellulase also have other cellulolytic and xylanolytic enzymes. Crude $\alpha$-L-arabinofuranosidase was used at $4.0 \mathrm{U} / \mathrm{g}$, crude xylanase was used at $300 \mathrm{U} / \mathrm{g}$, while commercial cellulase was used at 5.0 FPU/g during saccharification of maize stover. The enzymatic hydrolysis was performed in 150-ml screw cap Erlenmeyer flasks containing $2.5 \%$ pretreated and untreated maize stover and diluted enzyme, as mentioned earlier, in $50 \mathrm{mM}$ sodium citrate buffer $(\mathrm{pH} 4.8)$ containing $0.1 \%$ Tween 80 in a final volume of $40 \mathrm{ml}$. Controls were kept for each reaction in which the active enzyme was replaced with heat-inactivated enzyme. The reaction system was fortified with $10 \mathrm{mg} \%$ sodium azide. The reaction was carried out at $50^{\circ} \mathrm{C}$ in water bath with mild shaking. The samples were withdrawn every $4 \mathrm{~h}$ and incubated in boiling water bath $\left(100^{\circ} \mathrm{C}\right)$ to inactivate the enzyme; the reaction mixture was then filtered through wet muslin cloth by thorough squeezing and centrifuged to collect the clear supernatant. This supernatant was used for further analysis to estimate total reducing sugar by DNS method.

\section{Enzymatic hydrolysis of pretreated maize stover using commercial cellulase supplemented with crude xylanase and crude $a-L$-arabinofuranosidase}

The enzymatic hydrolysis of alkali $(\mathrm{NaOH})$-treated maize stover was performed using commercial cellulase (5.0 FPU/g), crude xylanase from $A$. foetidus MTCC 4898 (300 U/g), and crude $\alpha$-L-arabinofuranosidase from $A$. niger $\mathrm{ADH}-11$ $(4.0 \mathrm{U} / \mathrm{g})$ individually and cocktail of all. The reaction system was same as described in 'Enzymatic hydrolysis of maize stover' section. The hydrolysed products were analyzed by high-performance liquid chromatography (HPLC; Phenomenex, Rezex ROA-organic acid H+, 
column; Phenomenex Inc, Torrance, CA, USA). The degree of synergy or synergy is defined as 'the ratio of the yield of product released by enzymes when used together to the sum of yield of these products when the enzymes are used separately in the same amounts as they were employed in the mixture'.

\section{Results and discussion}

a-L-Arabinofuranosidase production using different agro residues under SSF

The production of $\alpha$-L-arabinofuranosidase was carried out using various agro residues like wheat bran, wheat straw, rice bran, rice straw, corn cobs, and maize bran as a sole carbon source and MandelsWeber medium as a moistening agent at $30^{\circ} \mathrm{C}$ under SSF. It was observed that all six substrates supported production of $\alpha$ - $\mathrm{L}$-arabinofuranosidase but wheat bran was found to be the most appropriate substrate under SSF, yielding a maximum yield of $\alpha$-Larabinofuranosidase up to $9.45 \mathrm{U} / \mathrm{g}$ after $192 \mathrm{~h}$ of incubation (Figure 1); hence, wheat bran was selected as the substrate for production of $\alpha$-L-arabinofuranosidase. The biochemical composition of wheat bran indicates that it contains predominantly non-starch carbohydrate polymers (approximately 58\%), starch (approximately 19\%), and crude protein (approximately 18\%). The nonstarch carbohydrate polymers are being primarily approximately $70 \%$ arabinoxylans, approximately $24 \%$ cellulose, and approximately $6 \% \beta-(1,3)(1,4)$-glucan [27]. The presence of higher amount of arabinoxylans in wheat bran may have induced $\alpha-\mathrm{L}-$ arabinofuranosidase production. Relatively very few attempts have been reported on the production of these enzymes under SSF. Khandeparker et al. [28] reported wheat bran was the best substrate for $\alpha$-L-arabinofuranosidase production by Arthrobacter sp. MTCC 5214 under SSF.

\section{Optimization of a-L-arabinofuranosidase production under SSF using response surface methodology}

Response surface methodology has been successfully applied for the optimization of fermentation medium components, conditions for enzymatic hydrolysis, and fermentation processes [29-32]. It predicts the maximum enzyme production among the selected range of variables and also studies the interaction among independent variables.

In the present study, the effect of urea, ammonium sulfate, proteose peptone, yeast extract, $\mathrm{KH}_{2} \mathrm{PO}_{4}, \mathrm{CaCl}_{2}$, $\mathrm{MgSO}_{4}, \mathrm{pH}$, moisture ratio, and fermentation time was evaluated on the basis of $\alpha$-L-arabinofuranosidase production using PBD (Table 1). Among these variables, urea, ammonium sulfate, $\mathrm{KH}_{2} \mathrm{PO}_{4}, \mathrm{CaCl}_{2}, \mathrm{MgSO}_{4}, \mathrm{pH}$, and fermentation time were identified as the most significant and contributing variables (Table 3) for $\alpha$-L-arabinofuranosidase production (Figure 2a). These parameters were further analyzed as variables using BBD for better production of $\alpha$ L-arabinofuranosidase.

The result of 54 run $\mathrm{BBD}$ in six variables urea, ammonium sulfate, $\mathrm{KH}_{2} \mathrm{PO}_{4}, \mathrm{CaCl}_{2}, \mathrm{MgSO}_{4}, \mathrm{pH}$, and fermentation time for the optimization of $\alpha$ - $\mathrm{L}$-arabinofuranosidase production is shown in Table 5.

The experimental results suggest that the variables selected for the fermentation process had a strong effect on $\alpha$-L-arabinofuranosidase production. On the basis of these experimental values, statistical testing was carried out using Minitab 16.0. The analysis of the model was tested by Fisher's $F$ test and Student's $T$ test. ANOVA of $\alpha$-L-arabinofuranosidase production showed that the response surface model was significant $(P=0.002)$ (Table 6) due to the square portion of the regression model. A $P$ value below 0.05 indicates that the test parameters are significant. In common, the larger the magnitude of $T$ and smaller the value of $P$, more significant is the consequent coefficient term [33]. The fitted second-order response surface model as specified by Equation 2 for $\alpha$-L-arabinofuranosidase yield in coded process variables is as follows:

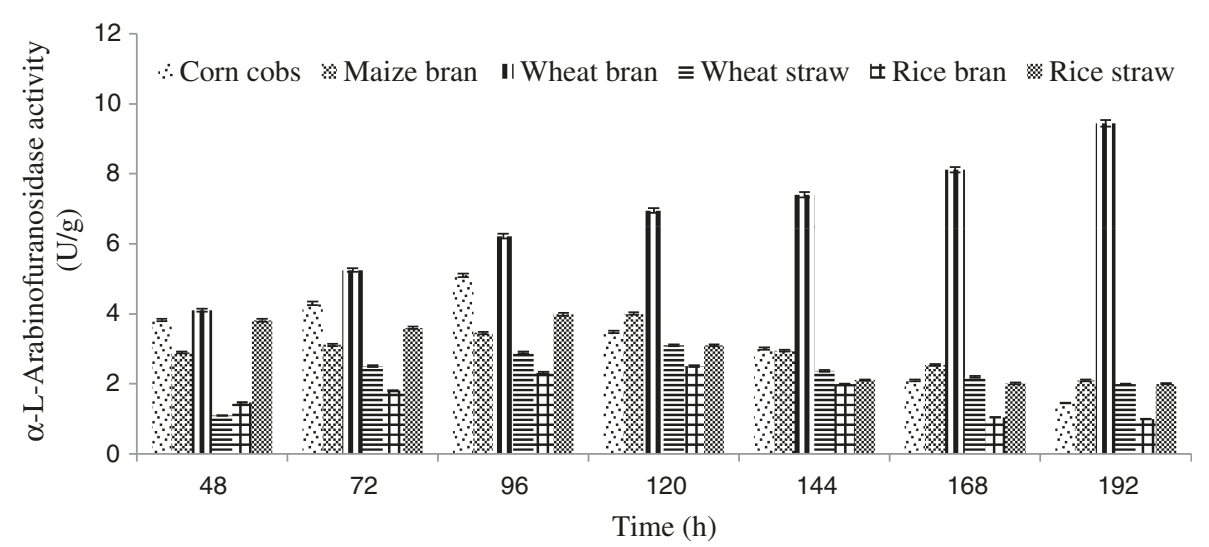

Figure 1 a-L-Arabinofuranosidase production using agro-residues under solid-state fermentation at $30^{\circ} \mathrm{C}$. 


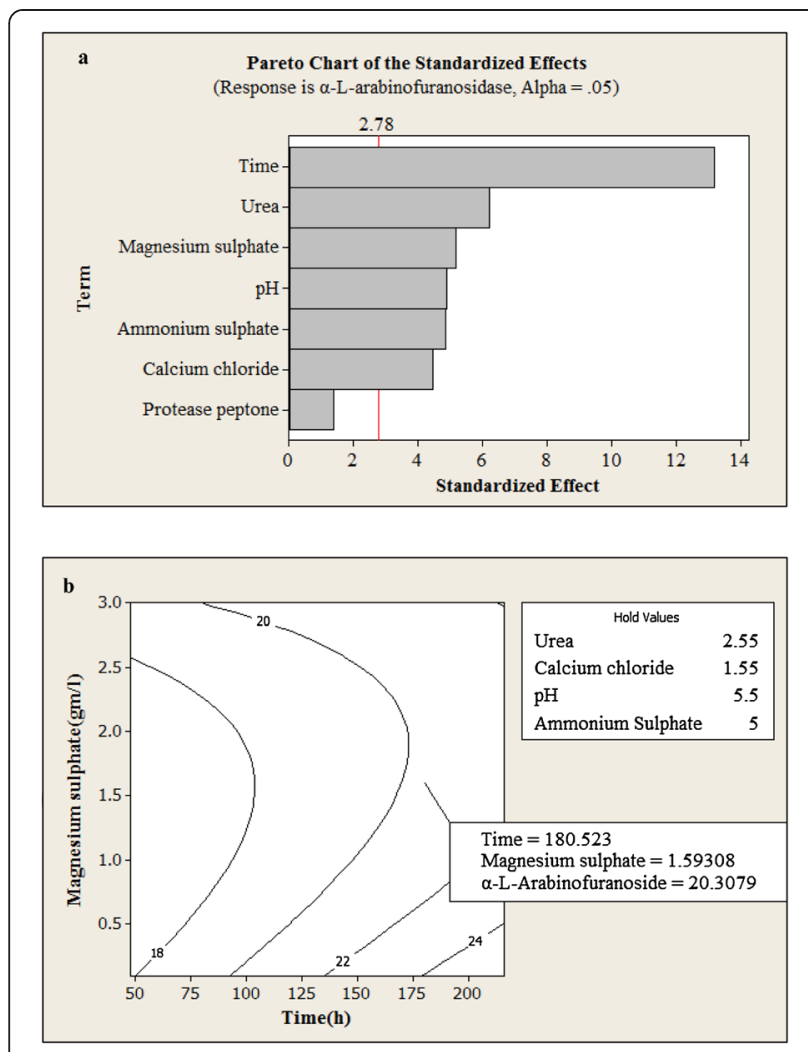

Figure 2 Pareto chart and contour plot. (a) Pareto chart showing effect of media components on a-L-arabinofuranosidase production. (b) Contour plot showing interaction of $\mathrm{MgSO}_{4}$ and incubation time on a-L-arabinofuranosidase production at hold values of urea, $\mathrm{CaCl}_{2}$, ammonium sulfate and $\mathrm{pH}$.

$$
\begin{aligned}
Y= & 18.9983+0.4454 x_{1}-0.4446 x_{2}-0.0054 x_{3} \\
& -0.5050 x_{4}+0.8204 x_{5}+2.5971 x_{6}+0.5010 x_{1}{ }^{2} \\
& +2.4422 x_{2}{ }^{2}-0.2028 x_{3}^{2}+5997 x_{4}{ }^{2}-2.7403 x_{5}{ }^{2} \\
& -0.0628 x_{6}{ }^{2}+0.6138 x_{1} x_{2}+1.8538 x_{1} x_{3} \\
& -1.2113 x_{1} x_{6}+0.7537 x_{2} x_{5}-1.2925 x_{2} x_{6} \\
& +0.6838 x_{3} x_{4}+1.0675 x_{3} x_{5}-0.2487 x_{4} x_{6} \\
& +0.1500 x_{5} x_{6}
\end{aligned}
$$

where $Y$ is $\alpha$-L-arabinofuranosidase yield square root of the predicted response, and $x_{1}, x_{2}, x_{3}, x_{4}, x_{5}$, and $x_{6}$ are the coded values of urea, $\mathrm{MgSO}_{4}, \mathrm{CaCl}_{2}, \mathrm{pH}$, ammonium sulfate, and fermentation time, respectively. A comparison of the experimentally obtained values of the enzyme with the predicted values indicated that these data are in reasonable agreement with predictive values (Table 5).

The corresponding $P$ value showed that the independent variable $\mathrm{MgSO}_{4}$ (X2) and fermentation time (X6) had significant effect $(0.003,0.000)$ on $\alpha$-L-arabinofuranosidase yield (Table 7). A significant interaction was also observed between urea (X1) and $\mathrm{CaCl}_{2}(\mathrm{X} 3)$ and between $\mathrm{pH}(\mathrm{X} 4)$ and ammonium sulfate (X5) $(0.034,0.035)$ contributing to the response at significant level for $\alpha$-L-arabinofuranoside production (Table 7). The $R^{2}$ value provides a measure of variability in the observed response value that can be explained by the experimental factors and their interactions. The coefficient $R^{2}$ of $\alpha$-L-arabinofuranoside was $76.4 \%$.

The fitted response for the above regression model was plotted in contour plot (Figure 2b) for the pairs of interactive variables while keeping other variables at their predicted optimum level. Among the variables, $\mathrm{MgSO}_{4}(\mathrm{X} 2)$, $\mathrm{CaCl}_{2}$ (X3), $\mathrm{pH}(\mathrm{X} 4)$, and fermentation time (X6) were the most significantly linear and had a positive effect on enzyme production. The significant interaction was observed between $\mathrm{MgSO}_{4}$ (X2) and fermentation time (X6) for $\alpha$-Larabinofuranosidase production. Increasing the fermentation time (X6) up to certain level may lead to an increase in $\alpha$-L-arabinofuranosidase yield, while increasing the $\mathrm{MgSO}_{4}$ (X2) up to $2.55 \mathrm{~g} / \mathrm{l}$ may lead to a drastic decrease in the $\alpha$-L-arabinofuranosidase yield. $\mathrm{MgSO}_{4}$ is considered as a good stimulator of mycelial growth which decreases the dormancy of the spores and can affect the enzyme yields [34]. Guerfali et al. [35] performed PBD followed by $\mathrm{CCD}$ and found that $\mathrm{MgSO}_{4}$ played an important role in

\begin{tabular}{|c|c|c|c|c|c|c|}
\hline Source & Degree of freedom & Sequential sums of squares & Adjusted sums of squares & Adjusted mean squares & $F$ value & $P$ value \\
\hline Regression & 27 & 464.93 & 464.93 & 17.220 & 3.12 & 0.002 \\
\hline Linear & 6 & 193.24 & 193.24 & 32.207 & 5.84 & 0.001 \\
\hline Square & 6 & 123.23 & 123.23 & 20.539 & 3.73 & 0.008 \\
\hline Interaction & 15 & 148.46 & 148.46 & 9.897 & 1.80 & 0.092 \\
\hline Residual error & 26 & 143.28 & 143.28 & 5.511 & & \\
\hline Lack-of-fit & 21 & 127.27 & 127.27 & 6.061 & 1.89 & 0.249 \\
\hline Pure error & 5 & 16.00 & 16.00 & 3.201 & & \\
\hline Total & 53 & 608.21 & & & & \\
\hline
\end{tabular}
$\alpha$ - $\mathrm{L}$-arabinofuranosidase production.

The application of RSM with BBD predicted that the maximum $\alpha$-L-arabinofuranosidase production will be up to $20.30 \mathrm{U} / \mathrm{g}$ at decoded values of process parameters as $\mathrm{MgSO}_{4} 1.59$, urea $2.55, \mathrm{CaCl}_{2} 1.55$, and ammonium

Table 6 ANOVA for the response surface quadratic model for $a$-L-arabinofuranosidase production 
Table 7 Regression coefficient for $\boldsymbol{a}$-L-arabinofuranosidase production

\begin{tabular}{|c|c|c|c|c|}
\hline Term & Coefficient & Standard error coefficient & $T$ value & $P$ value \\
\hline Constant & 18.9983 & 0.9583 & 19.824 & 0.000 \\
\hline Urea & 0.4454 & 0.4792 & 0.930 & 0.361 \\
\hline $\mathrm{MgSO}_{4}$ & -0.4246 & 0.4792 & -0.886 & 0.384 \\
\hline $\mathrm{CaCl}_{2}$ & -0.0054 & 0.4792 & -0.011 & 0.991 \\
\hline $\mathrm{pH}$ & -0.5050 & 0.4792 & -1.054 & 0.302 \\
\hline Ammonium sulfate & 0.8204 & 0.4792 & 1.712 & 0.099 \\
\hline Fermentation time & 2.5997 & 0.4792 & 5.420 & 0.000 \\
\hline Urea $\times$ Urea & 0.5010 & 0.7319 & 0.684 & 0.500 \\
\hline $\mathrm{MgSO}_{4} \times \mathrm{MgSO}_{4}$ & 2.4422 & 0.7319 & 3.337 & 0.003 \\
\hline $\mathrm{CaCl}_{2} \times \mathrm{CaCl}_{2}$ & -0.2028 & 0.7319 & -0.277 & 0.784 \\
\hline $\mathrm{pH} \times \mathrm{pH}$ & 0.5997 & 0.7319 & 0.819 & 0.420 \\
\hline Ammonium sulfate $\times$ Ammonium sulfate & -2.7403 & 0.7319 & -3.744 & 0.001 \\
\hline Fermentation time $\times$ Fermentation time & -0.0628 & 0.7319 & -0.086 & 0.932 \\
\hline Urea $\times \mathrm{MgSO}_{4}$ & 0.6138 & 0.8300 & 0.739 & 0.466 \\
\hline Urea $\times \mathrm{CaCl}_{2}$ & 1.8538 & 0.8300 & 2.234 & 0.034 \\
\hline Urea $\times \mathrm{pH}$ & 0.4800 & 0.5869 & 0.818 & 0.421 \\
\hline Urea $\times$ Ammonium sulfate & -0.6538 & 0.8300 & -0.788 & 0.438 \\
\hline Urea $\times$ Fermentation time & -1.2113 & 0.8300 & -1.459 & 0.156 \\
\hline $\mathrm{MgSO}_{4} \times \mathrm{CaCl}_{2}$ & -1.2425 & 0.8300 & -1.497 & 0.146 \\
\hline $\mathrm{MgSO}_{4} \times \mathrm{pH}$ & 0.6838 & 0.8300 & 0.824 & 0.418 \\
\hline $\mathrm{MgSO}_{4} \times$ Ammonium sulfate & 0.7537 & 0.5869 & 1.284 & 0.210 \\
\hline $\mathrm{MgSO}_{4} \times$ Fermentation time & -1.2925 & 0.8300 & -1.557 & 0.131 \\
\hline $\mathrm{CaCl}_{2} \times \mathrm{pH}$ & 1.6750 & 0.8300 & 2.018 & 0.054 \\
\hline Ammonium sulfate $\times$ Fermentation time & 1.0675 & 0.8300 & 1.286 & 0.210 \\
\hline $\mathrm{CaCl}_{2} \times$ Ammonium sulfate & -0.2706 & 0.5869 & -0.461 & 0.649 \\
\hline $\mathrm{CaCl}_{2} \times$ Fermentation time & -0.2487 & 0.8300 & -0.300 & 0.767 \\
\hline $\mathrm{pH} \times$ Ammonium sulfate & 1.8425 & 0.8300 & 2.220 & 0.035 \\
\hline $\mathrm{pH} \times$ Fermentation time & 0.1500 & 0.8300 & 0.181 & 0.858 \\
\hline
\end{tabular}

sulfate $5 \mathrm{~g} / \mathrm{l}$ with initial $\mathrm{pH} 5.5$ after incubation $180 \mathrm{~h}$ of fermentation time.

\section{Validation of the experimental model}

A repeat fermentation for $\alpha$ - $\mathrm{L}$-arabinofuranosidase production was carried out under optimal conditions to validate the parameters predicted by the model. The $\alpha$-L-arabinofuranosidase production under optimized parameters viz. $\mathrm{MgSO}_{4} 1.59$, urea 2.55, $\mathrm{CaCl}_{2}$ 1.55, and ammonium sulfate $5 \mathrm{~g} / \mathrm{l}$ at $\mathrm{pH} 5.5$ and fermentation time of $180 \mathrm{~h}$ yielded $\alpha$-L-arabinofuranosidase activity of $22.14 \mathrm{U} / \mathrm{g}$ $(3.16 \mathrm{U} / \mathrm{ml})$. This was significantly higher than the predicted value (20.30) by the model. Crude enzyme extract also contained $140 \mathrm{U} / \mathrm{g}(20.0 \mathrm{U} / \mathrm{ml})$ endo-xylanase, $70.0 \mathrm{U} / \mathrm{g}$ $(10.0 \mathrm{U} / \mathrm{ml}) \beta$-xylosidase, and $0.14 \mathrm{U} / \mathrm{g}(0.02 \mathrm{U} / \mathrm{ml})$ filter paper activity. Thus, it was proved that the statistical optimization increased $\alpha$-L-arabinofuranosidase production by 2.34 -fold as compared to their initial production which was $9.45 \mathrm{U} / \mathrm{g}(1.35 \mathrm{U} / \mathrm{ml})$ before statistical optimization. Khandeparker [28] reported a maximum $3 \mathrm{U} / \mathrm{g}$ of $\alpha-\mathrm{L}-$ arabinofuranosidase production after $120 \mathrm{~h}$ of incubation by Arthrobacter sp. MTCC 5214 under SSF. Guerfali et al. [35] reported a maximum $0.6 \mathrm{U} / \mathrm{ml}$ of $\alpha-\mathrm{L}$ arabinofuranosidase production after $120 \mathrm{~h}$ of incubation by Talaromyces thermophilus using response surface methodology under submerged fermentation. Hence, newly isolated $A$. niger $\mathrm{ADH}-11$ was found to be a strong producer of $\alpha$-L-arabinofuranosidase; however, the fermentation time was higher as compared to other reports.

\section{Effect of temperature and $\mathrm{pH}$ on $\mathrm{a}-\mathrm{L}$-arabinofuranosidase activity}

The influence of temperature on $\alpha$-L-arabinofuranosidase activity was evaluated in the range of $40^{\circ} \mathrm{C}$ to $75^{\circ} \mathrm{C}$. The results revealed that the optimum temperature for $\alpha-\mathrm{L}$ arabinofuranosidase activity was $55^{\circ} \mathrm{C}$ (Figure 3a). $\alpha-\mathrm{L}-$ 

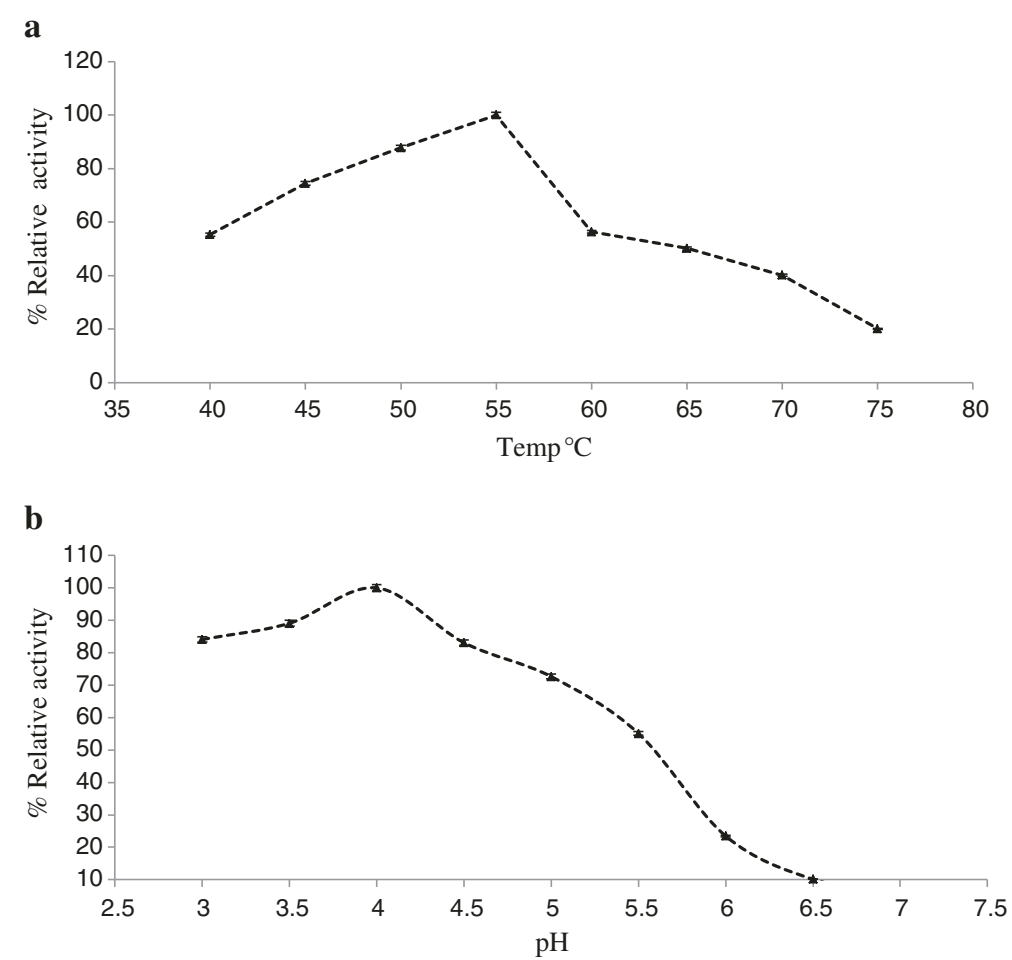

Figure 3 Effect of temperature (a) and pH (b) on a-L-arabinofuranosidase activity.
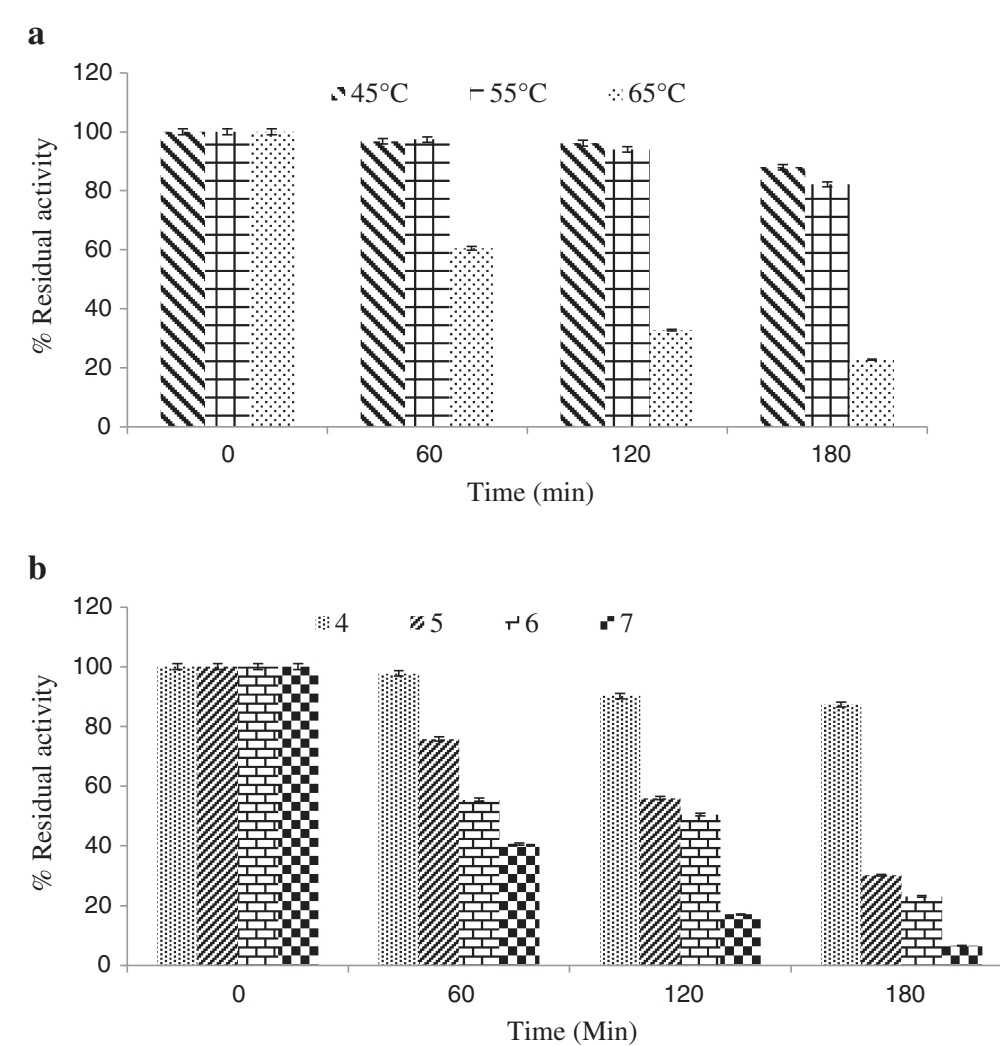

Figure 4 Thermal stability (a) and pH stability (b) of a-L-arabinofuranosidase. 
Arabinofuranosidase activity was reduced by only $13 \%$ and $44 \%$ at $50^{\circ} \mathrm{C}$ and $60^{\circ} \mathrm{C}$, respectively. The result was similar to many $\alpha$-L-arabinofuranosidases from different strains of fungi [36]. Guerfali et al. [35] also reported that the optimum temperature of $\alpha$-L-arabinofuranosidase from Talaromyces thermophilus was $55^{\circ} \mathrm{C}$.

The $\alpha$-L-arabinofuranosidase activity at various $\mathrm{pH}$ (3 to 7) was measured using $p$-nitrophenyl- $\alpha$-L-arabinofuranoside as a substrate at $55^{\circ} \mathrm{C}$. The optimum $\mathrm{pH}$ for $\alpha-\mathrm{L}$ arabinofuranosidase activity was found to be at 4 (Figure $3 \mathrm{~b}$ ). The enzyme was remarkably active even at $\mathrm{pH} 3.5$ and 4.5 , with loss of only $11 \%$ and $17 \%$ activities. Kaneko et al. [37] also found the optimum $\mathrm{pH}$ as 4.0 for $\alpha$-L-arabinofuranosidase from $A$. niger 5-16. Most of the fungal $\alpha$-L-arabinofuranosidases exhibited acidic $\mathrm{pH}$ in the range of 4.0 to 5.0 . The enzyme activity is markedly affected by variation in $\mathrm{pH}$ outside its optimum $\mathrm{pH}$. This may be due to substrate binding and catalysis, which are often affected by charge distribution on both substrate and enzyme molecules [38].

\section{Temperature and $\mathrm{pH}$ stability of $\mathrm{a}$-L-arabinofuranosidase}

The $\alpha$-L-arabinofuranosidase from A. niger $\mathrm{ADH}-11$ was found to be highly stable in the range of $45^{\circ} \mathrm{C}$ to $55^{\circ} \mathrm{C}$ (Figure $4 \mathrm{a}$ ). At $55^{\circ} \mathrm{C}$ the enzyme retained $82.38 \%$ of its activity after $3 \mathrm{~h}$. Yan et al. [39] reported that $\alpha$-Larabinofuranosidase from Chaetomium sp. was stable at $55^{\circ} \mathrm{C}$ for $30 \mathrm{~min}$. Guais et al. [40] found that $\alpha-\mathrm{L}-$ arabinofuranosidase activity was dropped by $50 \%$ at $60^{\circ} \mathrm{C}$ after $12 \mathrm{~min}$. The $\alpha$-L-arabinofuranosidase could retain its activity up to $87.37 \%$ at $\mathrm{pH} 4$ after incubation of $3 \mathrm{~h}$ (Figure $4 \mathrm{~b}$ ). The activity of $\alpha$-L-arabinofuranosidase was gradually
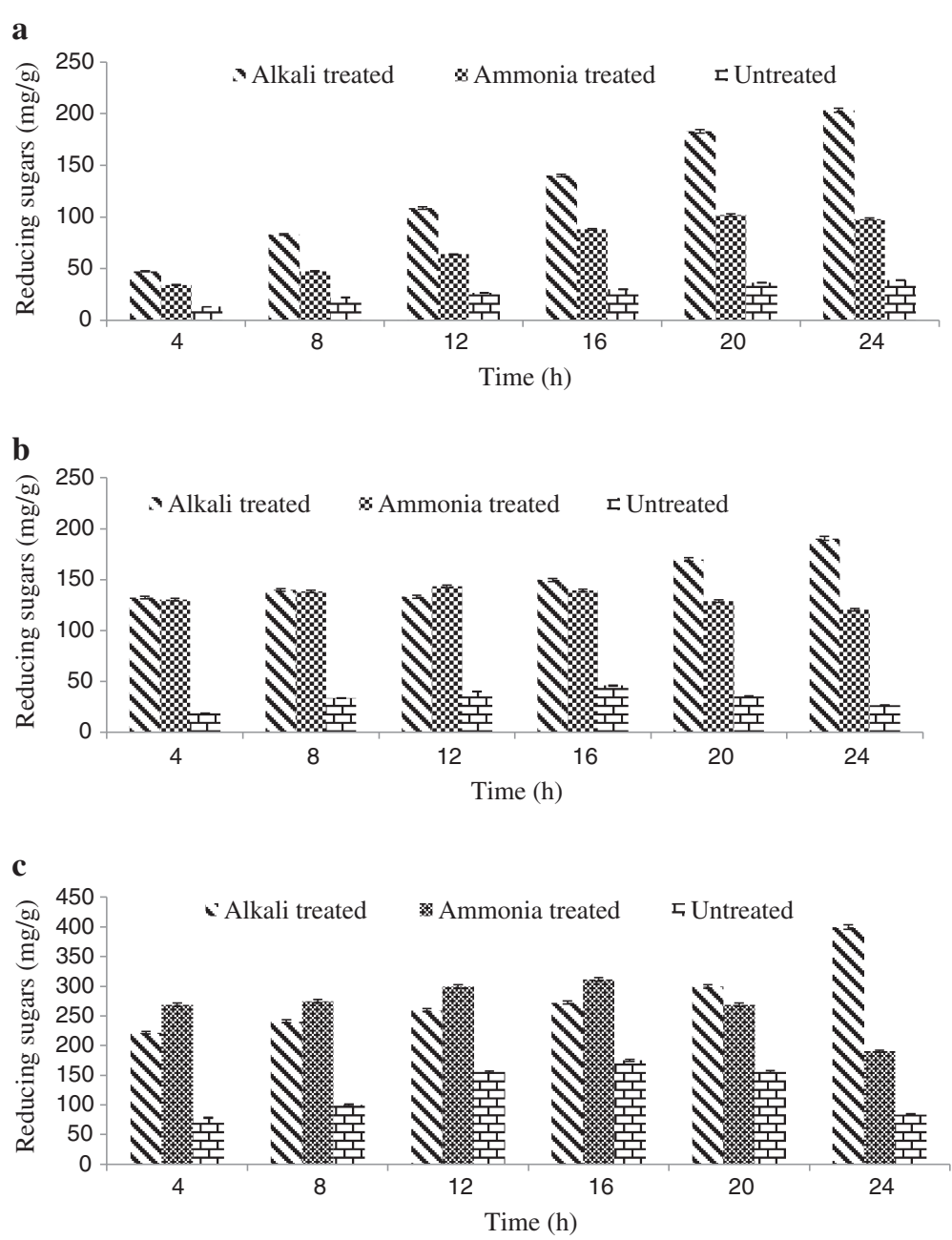

Figure 5 Enzymatic hydrolysis of untreated and alkali (NaOH)- and ammonia treated maize stover using different enzymes. (a) Enzymatic hydrolysis of untreated and alkali- and ammonia-treated maize stover using $4.06 \mathrm{U} / \mathrm{g}$ crude a-L-arabinofuranosidase at $50^{\circ} \mathrm{C}$. (b) Enzymatic hydrolysis of untreated and alkali-, and ammonia-treated maize stover using $300 \mathrm{U} / \mathrm{g}$ crude xylanase at $50^{\circ} \mathrm{C}$. (c) Enzymatic hydrolysis of untreated and alkali- and ammonia-treated maize stover using $5.0 \mathrm{FPU} / \mathrm{g}$ commercial cellulase at $50^{\circ} \mathrm{C}$. 
Table 8 Composition of enzymes in each cocktail

\begin{tabular}{|c|c|c|c|c|c|c|c|}
\hline Enzyme & $\begin{array}{l}\beta-X y l o s i d a s e \\
(U / \mathrm{ml})\end{array}$ & $\begin{array}{l}\text { a-L-Arabinofuranosidase } \\
(\mathrm{U} / \mathrm{ml})\end{array}$ & $\begin{array}{c}\text { Feruloyl } \\
\text { esterase }(\mathrm{U} / \mathrm{ml})\end{array}$ & $\begin{array}{l}\text { Xylanase } \\
(\mathrm{U} / \mathrm{ml})\end{array}$ & $\begin{array}{c}\text { Filter paper } \\
\text { activity }(\mathrm{U} / \mathrm{ml})\end{array}$ & $\begin{array}{l}\text { Endoglucanase } \\
\qquad(\mathrm{U} / \mathrm{ml})\end{array}$ & $\begin{array}{c}\beta \text {-Glucosidase } \\
(\mathrm{U} / \mathrm{ml})\end{array}$ \\
\hline $\begin{array}{l}\text { Crude } a-L- \\
\text { arabinofuranosidase }^{a}\end{array}$ & 10.0 & 3.16 & 1.0 & 20.0 & 0.02 & 5.56 & 0.18 \\
\hline Crude xylanase $^{b}$ & 0.2 & ND & ND & 375.0 & 0.12 & 4.5 & 0.20 \\
\hline Commercial cellulase $^{c}$ & ND & ND & ND & 300.0 & 43.9 & $2,798.0$ & 43.0 \\
\hline
\end{tabular}

${ }^{a}$ Crude a-L-arabinofuranosidase from A. niger ADH-11; ${ }^{b}$ Crude xylanase from A. foetidus MTCC 4898 ; ${ }^{\mathrm{C}}$ Commercial cellulase MAPs 450 . ND, not detected.

reduced to $30.21 \%$ and $23.07 \%$ at pH 5 and 6 after 3 h, respectively, while only $6.59 \%$ activity was retained at $\mathrm{pH} 7$ after $3 \mathrm{~h}$. Filho et al. [41] reported that $\alpha$-Larabinofuranosidases I and II from Penicillium capsulatum retained 50\% activity at $\mathrm{pH} 4.0$ after 9 and $17.5 \mathrm{~min}$, respectively. Yan et al. [39] reported that $\alpha-\mathrm{L}$ arabinofuranosidase from Chaetomium sp. retained $80 \%$ activity at $\mathrm{pH} 4.0$ after $30 \mathrm{~min}$. In comparison to the above reports, the crude $\alpha$-L-arabinofuranosidase from $A$. niger $\mathrm{ADH}-11$ was found to be more stable at high temperature and low $\mathrm{pH}$, so it can be suitable for saccharification of lignocellulosic biomass along with commercial cellulases.

\section{Enzymatic hydrolysis of maize stover}

The major conversion steps in biochemical production of cellulosic biofuels are pretreatment and enzymatic hydrolysis. Together, these steps work to breakdown the cellulose and hemicelluloses found in the cell walls of plants (biomass) to simple sugars which can then can be fermented to ethanol. Maize stover is currently the largest waste biomass in the India, consisting of more than one-third of the total solid waste produced. Maize stover typically contains $70 \%$ cellulose and hemicellulose and $15 \%$ to $20 \%$ lignin. Ammonia and $\mathrm{NaOH}$-pretreated maize stover were used to test the ability of the crude $\alpha$-L-arabinofuranosidase, crude xylanase, and commercial cellulase for the production of fermentable sugar by saccharification. Maximum reducing sugars of $203.6 \mathrm{mg} / \mathrm{g}$ were produced using crude $\alpha-\mathrm{L}$ arabinofuranosidase, while crude xylanase and commercial cellulase yielded 190.7 and $400.0 \mathrm{mg} / \mathrm{g}$ respectively using $\mathrm{NaOH}$-pretreated maize stover (Figure 5a,b,c). A higher yield of reducing sugars was achieved when the substrate was pretreated with $\mathrm{NaOH}$ as compared to ammonia.

The maximum bioconversion of lignocellulosic biomass requires action of not only efficient cellulolytic enzymes but also main chain depolymerizing and debranching hemicellulolytic enzymes at appropriate levels. It is evident from Table 8 that the commercial enzyme used in this study was deficient in $\beta$-xylosidase, $\alpha$-L-arabinofuranosidase, and feruloyl esterase and hence, the indigenously produced crude $\alpha$-L-arabinofuranosidase was supplemented to form a balanced enzyme cocktail for saccharification of alkali-pretreated maize stover. There was a remarkable increase in $\beta$-xylosidase, $\alpha$-L-arabinofuranosidase, feruloyl esterase, endo-xylanase, and $\beta$-glucosidase loading upon supplementation of crude $\alpha$-L-arabinofuranosidase to commercial cellulase-crude xylanase cocktail (Table 9). As shown in Figure 6, the cocktail produced maximum $730.1 \mathrm{mg} / \mathrm{g}$ of reducing sugar after $24 \mathrm{~h}$ which was higher as compared to each enzyme used alone (crude $\alpha$-L-arabinofuranosidase $203.6 \mathrm{mg} / \mathrm{g}$, crude xylanase $134.4 \mathrm{mg} / \mathrm{g}$, and commercial cellulase $294.1 \mathrm{mg} / \mathrm{g}$, respectively) for saccharification. The co-action of crude $\alpha$ L-arabinofuranosidase with commercial cellulase-crude xylanase produced a superior saccharification yield. The HPLC analysis of enzymatic hydrolysates revealed synergistic rise in glucose, xylose, and arabinose (degree of synergy $1.21,1.00$, and 1.33, respectively). The levels of glucose, xylose, and arabinose were 5.57, 4.99, and $0.64 \mathrm{mg} / \mathrm{ml}$ when the cocktail was used (Table 10). Thus, the supplementation of crude $\alpha$-L-arabinofuranosidase $(4.0 \mathrm{U} / \mathrm{g})$ with commercial cellulase and crude xylanase increased the glucose yield up to $176.8 \%$ and xylose yield up to $166.8 \%$ (Table 10). Although supplementation of crude xylanase with commercial cellulase increased the

Table 9 Enzyme loading for saccharification of pretreated maize stover

\begin{tabular}{|c|c|c|c|c|c|c|c|}
\hline Enzyme & $\begin{array}{c}\beta \text {-Xylosidase } \\
(\mathrm{U} / \mathrm{g})\end{array}$ & $\begin{array}{c}\text { a-L-Arabinofuranosidase } \\
(\mathrm{U} / \mathrm{g})\end{array}$ & $\begin{array}{c}\text { Feruloyl } \\
\text { esterase }(\mathrm{U} / \mathrm{g})\end{array}$ & $\begin{array}{l}\text { Xylanase } \\
(\mathrm{U} / \mathrm{g})\end{array}$ & $\begin{array}{c}\text { Filter paper } \\
\text { activity (U/g) }\end{array}$ & $\begin{array}{l}\text { Endoglucanase } \\
\text { (U/g) }\end{array}$ & $\begin{array}{c}\beta \text {-Glucosidase } \\
(\mathrm{U} / \mathrm{g})\end{array}$ \\
\hline $\begin{array}{l}\text { Crude a-L- } \\
\text { arabinofuranosidase }^{a}\end{array}$ & 12.7 & 4.0 & 1.27 & 25.4 & 0.025 & 7.06 & 0.22 \\
\hline Crude $x y l a n a s e^{b}$ & 0.16 & ND & ND & 300 & 0.09 & 3.6 & 0.16 \\
\hline Commercial cellulase $^{c}$ & ND & ND & ND & 33.0 & 5.0 & 307.7 & 4.78 \\
\hline
\end{tabular}

${ }^{a}$ Crude a-L-arabinofuranosidase from A. niger ADH- $11 ;{ }^{b}$ Crude xylanase from A. foetidus MTCC $4898 ;{ }^{c}$ Commercial cellulase MAPs 450 . ND, not detected. 


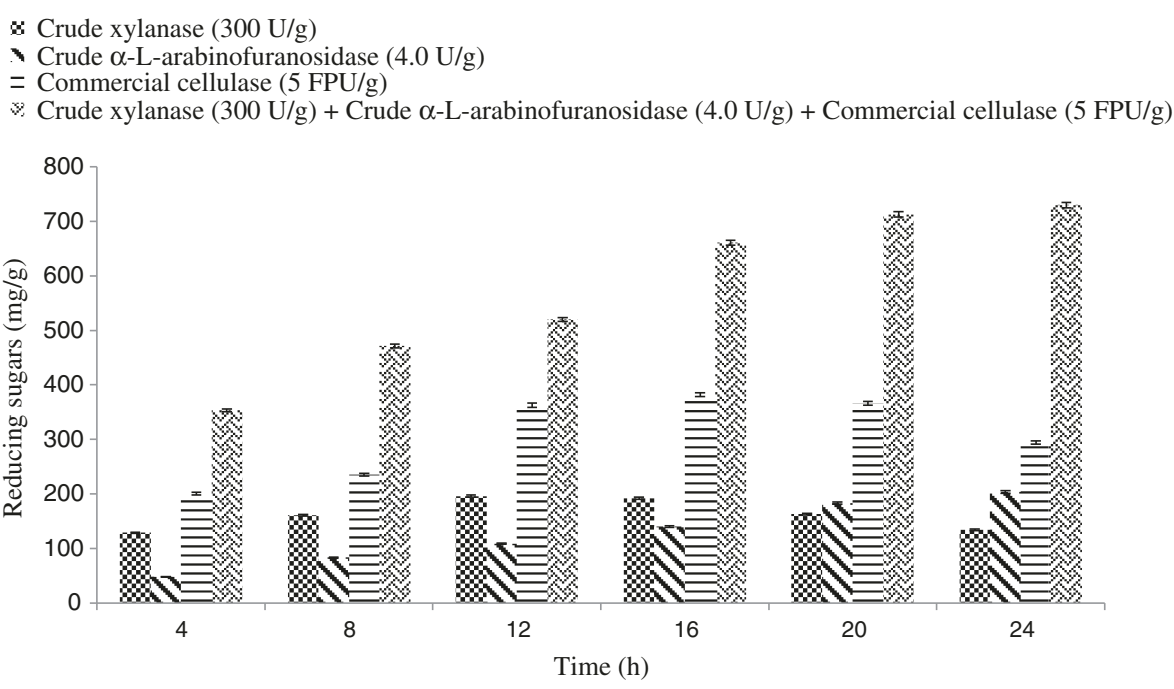

Figure 6 Enzymatic hydrolysis of alkali-treated maize stover using individual and cocktail of different enzymes. Enzymatic hydrolysis of alkali-treated maize stover using individual and cocktails of crude $\mathrm{a}$-L-arabinofuranosidase, crude xylanase, and commercial cellulases at $50^{\circ} \mathrm{C}$.

loading of endoglucanase, $\beta$-glucosidase, and endoxylanase (Table 9), the yield of glucose, xylose, and arabinose was lesser compared to the cocktail of crude $\alpha$-L-arabinofuranosidase $(4.0 \mathrm{U} / \mathrm{g})$ with commercial cellulase (5 FPU/g) and crude xylanase $(300 \mathrm{U} / \mathrm{g})$ cocktail. These results clearly suggest that the higher yield of reducing sugars obtained by this cocktail was due to higher amount of $\alpha$-L-arabinofuranosidase and $\beta$-xylosidase enzymes which were contributed by the crude $\alpha$-Larabinofuranosidase produced by $A$. niger ADH-11. The presence of $\alpha$-L-arabinofuranosidase plays an important role by removing arabinose from the side chains of xylan, and $\beta$-xylosidase plays a crucial role in reducing the end product inhibition of xylanases by hydrolyzing xylobiose and hence facilitates better bioconversion of maize stover. A similar observation was reported by Delabona

\begin{tabular}{|c|c|c|c|}
\hline Enzyme cocktails & $\begin{array}{l}\text { Glucose } \\
(\mathrm{mg} / \mathrm{ml})\end{array}$ & $\begin{array}{l}\text { Xylose } \\
\text { (mg/ml) }\end{array}$ & $\begin{array}{c}\text { Arabinose } \\
(\mathrm{mg} / \mathrm{ml})\end{array}$ \\
\hline Commercial cellulase (5 FPU/g) & 2.98 & 1.69 & ND \\
\hline $\begin{array}{l}\text { Crude } a \text {-L-arabinofuranosidase } \\
(4.0 \mathrm{U} / \mathrm{g})\end{array}$ & 0.69 & 1.59 & 0.48 \\
\hline Crude xylanase (300 U/g) & 0.93 & 1.70 & ND \\
\hline $\begin{array}{l}\text { Commercial cellulase (5 FPU/g) + } \\
\text { Crude xylanase }(300 \mathrm{U} / \mathrm{g})\end{array}$ & 3.15 & 2.99 & ND \\
\hline $\begin{array}{l}\text { Commercial cellulase }(5 \mathrm{FPU} / \mathrm{g})+ \\
\text { Crude a-L-arabinofuranosidase } \\
(4.0 \mathrm{U} / \mathrm{g})+\text { Crude xylanase }(300 \mathrm{U} / \mathrm{g})\end{array}$ & 5.57 & 4.99 & 0.64 \\
\hline
\end{tabular}

$\mathrm{ND}$, not detected. et al. [42]. Their studies on sugarcane bagasse strongly suggested that the supplementation of $\alpha-\mathrm{L}$ arabinofuranosidase with commercial cellulase resulted in greater sugar release. The present study clearly demonstrated that the crude $\alpha$-L-arabinofuranosidase-rich enzyme obtained from A. niger ADH-11 can be used to enhance the efficiency of commercial cellulase for saccharification of biomass.

\section{Conclusions}

The present investigation showed that newly isolated $A$. niger $\mathrm{ADH}-11$ is a potential $\alpha$-L-arabinofuranosidase producer. The statistical optimization for $\alpha$-L-arabinofuranosidase production by SSF was highly advantageous as enzyme production was enhanced by 2.34 -fold. To the best of our knowledge, this report describes the highest level of $\alpha-\mathrm{L}$ arabinofuranosidase production under SSF. The crude enzyme was highly active and stable at $55^{\circ} \mathrm{C}$ and $\mathrm{pH} 4.0$, which makes it suitable for application in enzymatic saccharification of biomass. Moreover, it was evident from the present investigation that the supplementation of crude $\alpha$-L-arabinofuranosidase can play significant role in the enzymatic hydrolysis of maize stover.

\section{Competing interests}

The authors declare that they have no competing interests.

\section{Authors' contributions}

HP designed and performed the experiments along with the data analysis and organized the manuscript draft. JD designed and analyzed the statistical data for optimization of enzyme production. DC helped in designing the experiments and preparing the manuscript draft. AS supervised the complete study along with experimentation, interpretation, and manuscript preparation. All authors read and approved the final manuscript. 


\section{Acknowledgements}

The authors gratefully acknowledge Gujarat State Biotechnology Mission (GSBTM), Gandhinagar, Gujarat, India for providing the research grants to support this work. The authors are also thankful to MAPs Enzyme Limited, India for providing the cellulase enzyme.

\section{Author details}

${ }^{1}$ BRD School of Biosciences, Sardar Patel Maidan Satellite Campus, Sardar Patel University, PO Box No. 39, Vallabh Vidyanagar 388120, Gujarat, India. ${ }^{2}$ Department of Microbiology, Shree Ramkrishna Institute of Computer Education and Applied Sciences - MTB College Campus, Athwalines, Surat 395001, Gujarat, India. ${ }^{3}$ Department of Statistics, Sardar Patel University, Vallabh Vidyanagar 388120, Gujarat, India.

\section{Received: 5 December 2014 Accepted: 6 February 2015 Published online: 10 March 2015}

\section{References}

1. Aristidou A, Penttila M (2000) Metabolic engineering applications to renewable resource utilization. Curr Opin Biotechnol 39:1931-1938

2. Beg QK, Kapoor M, Mahajan L, Hoondal GS (2001) Microbial xylanases and their industrial applications: a review. Appl Microbiol Biotechnol 56:326-338

3. Cano A, Palet C (2007) Xylooligosaccharide recovery from agricultural biomass waste treatment with enzymatic polymeric membranes and characterization of products with MALDI-TOF-MS. J Membr Sci 291:96-105

4. Collins T, Gerday C, Feller G (2005) Xylanases, xylanase families and extremophilic xylanases. FEMS Microbiol Rev 29:3-23

5. Kaji A (1984) L-Arabinosidases. Adv Carbohydr Chem Biochem 42:383-394

6. Okafor UA, Okochi VI, Onyegeme-Okerenta BM, Nwodo-Chinedu S (2007) Xylanase production by Aspergillus niger ANL 301 using agro-wastes. Afr J Biotechnol 6(14):1710-1714

7. Potanen K (1988) An a-L-arabinofuranosidase of Trichoderma reesei. J Biotechnol 7:271-282

8. Kormelink FJM, MJF S-V I, Wood TM, Voragen AGJ (1991) Purification and characterization of a $(1,4)$ - $\beta$-arabinoxylan arabinofuranohydrolase from Aspergillus awamori. Appl Microbiol Biotechnol 35:753-758

9. Ramon D, Veen PVD, Visser J (1993) Arabinan degrading enzymes from Aspergillus nidulans: induction and purification. FEMS Microbiol Lett 113:15-22

10. Lounteri E, Siika-aho M, Tenkanen M, Viikari L (1995) Purification and characterization of three $a$-arabinosidases from Aspergillus terreus. J Biotechnol 38:279-291

11. loannes PD, Peirano A, Steiner J, Eyzaguirre J (2000) An a-Larabinofuranosidase from Penicillium purpurogenum: production, purification and properties. J Biotechnol 76:253-258

12. Hashimoto T, Nakata $Y$ (2003) Synergistic degradation of arabinoxylan with $a-L$-arabinofuranosidase, xylanase and $\beta$-xylosidase from soy sauce koji mold, Aspergillus oryzae, in high salt condition. J Biosci Bioeng 95(2):164-169

13. Sakamoto T, Kawasaki $H$ (2003) Purification and properties of two type-B a-L-arabinofuranosidases produced by Penicillium chrysogenium. Biochem Biophys Acta 1621:204-210

14. Tengerdy RP (1996) Solid state fermentation for enzyme production. In: Pandey A (ed) Advances in biotechnology. Educational Publishers and Distributors, New Delhi, pp 13-16

15. Shah A, Madamwar D (2005) Xylanase production under solid-state fermentation and its characterization by an isolated strain of Aspergillus foetidus in India. World J Microbiol Biotechnol 21:233-243

16. Barrios-Gonzalez J (2012) Solid-state fermentation: physiology of solid medium, its molecular basis and application. Process Biochem 47:175-185

17. Pandey A, Soccol CR, Mitchell D (2000) New development in solid state fermentation: I-bioprocesses and products. Process Biochem 35:1153-1169

18. Chapla D, Divecha J, Madamwar D, Shah A (2010) Utilization of agro-industria waste for xylanase production by Aspergillus foetidus MTCC 4898 under solid state fermentation and its application in saccharification. Biochem Eng J 49:361-369

19. Trivedi S, Divecha J, Shah A (2012) Optimization of inulinase production by a newly isolated Aspergillus tubingensis CR16 using low cost substrate. Carbo Poly 90:483-490

20. Li Y, Jiang $H, X u Y$, Zhang $X$ (2008) Optimization of nutrient components for enhance phenazine-1-carboxylic acid production by gacA-inactivated Pseudomonas sp. M18G using response surface method. Appl Microbiol Biotechnol 77:1207-1217
21. Min BJ, Park YS, Kang SW, Song YS, Lee JH, Park C, Kim CW, Kim SW (2007) Statistical optimization of medium components for the production of xylanase by Aspergillus niger KK2 in submerged cultivation. Biotechnol Bioprocess Eng 12:302-307

22. Yanai T, Sato M (2000) Purification and characterization of a novel a-L-arabinofuranosidase from Pichia capsulata X91. Biosci Biotechnol Biochem 64:1181-1188

23. Bailey MJ, Biely P, Poutanen K (1992) Interlaboratory testing of methods for assay of xylanase activity. J Biotechnol 23:257-270

24. Miller GL (1959) Use of dinitrosalicylic acid reagent for determination of reducing sugar. Anal Chem 31:426-428

25. Ghosh T (1994) Measurement of cellulase activities, Commission on Biotechnology. IUPAC., pp 1-12

26. Lowry OH, Rosebrough NJ, Farr AL, Randall RJ (1951) Protein measurement with the folin phenol reagent. J Biol Chem 31:426-428

27. Sun X, Liu Z, Qu Y, Li X (2008) The effect of wheat bran composition on the production of biomass hydrolyzing enzymes by Penicillium decumbens. Appl Biochem Biotechnol 146:119-128

28. Khandeparker R, Numan MTH, Mukherjee B, Satwekar A, Bhosle NB (2008) Purification and characterization of a-L-arabinofuranosidase from Arthrobacter sp. MTCC 5214 in solid state fermentation. Process Biochem 43:707-712

29. Narra M, Dixit G, Divecha J, Madamwar D, Shah A (2012) Production of cellulases by solid state fermentation with Aspergillus terreus and enzymatic hydrolysis of mild alkali-treated rice straw. Bioresour Technol 121:355-361

30. Ho SH, Anh TV, Koo YM (2013) Optimization of lipase-catalyzed synthesis of caffeic acid phenethyl ester in ionic liquid by response surface methodology. Bioprocess Biosys Eng 36:799-807

31. Katapodis P, Christakopoulou V, Kekos D, Christakopoulou P (2007) Optimization of xylanase production by Chaetomum thermophilum in wheat straw using response surface methodology. Biochem Eng J 35:136-141

32. Li Y, Cui F, Liu Z, Xu Y, Zhao H (2007) Improvement of xylanase production by Penicillium oxalicum $\mathrm{ZH}-30$ using response surface methodology. Enzym Microbial Technol 40:1381-1388

33. Montgomery DC (1991) Design and analysis of experiments, 7th edn. Wiley, New York. ISBN ISBN-978-0-470-12866-4

34. Kirillova IP, Agre N, Kalakutskii LB (1975) Effect of the composition of the medium and magnesium and calcium ions on the germination of spores of Thermoactinomyces vulgaris. Mikrobiologiia 44(6):1034-1040

35. Guerfali M, Chaabouni M, Gargouri A, Belgith H (2010) Improvement of a-L-arabinofuranosidase production by Talaromyces thermophilus and agro-industrial residues saccharification. Appl Microbiol Biotechnol 85:1361-1372

36. Saha BC (2000) a-L-Arabinofuranosidase: biochemistry, molecular biology and application in biotechnology. Biotechnol Adv 18:403-423

37. Kaneko S, Shimasaki T, Kusakabe I (1993) Purification and some properties of intracellular a-L-arabinofuranosidase from Aspergillus niger 5-16. Biosci Biotechnol Biochem 57:1161-1165

38. Shah AR, Madamwar D (2005) Xylanase production by a newly isolated Aspergillus foetidus strain and its characterization. Process Biochem 40:1763-1771

39. Yan Q, Tang L, Yang S, Zhou P, Zhang S, Jiang Z (2012) Purification and characterization of a novel thermostable $a$-L-arabinofuranosidase ( $a$-L-AFase) from Chaetomium sp. Process Biochem 47:472-478

40. Guais O, Tourrasse O, Dourdoigne M, Parrou JL, Francois JM (2010) Characterization of the family GH54 a-L-arabinofuranosidases in Penicillium funiculosum, including a novel protein bearing a cellulose-binding domain. Appl Microbiol Biotechnol 87:1007-1021

41. Filho EXF, Puls J, Coughlan MP (1996) Purification and characterization of two arabinofuranosidases from solid state culture of the fungus Penicillium capsulatum. Appl Environ Microbiol 62(1):168-172

42. Delabona PS, Cota J, Hoffmam ZB, Paixao DA, Farinas CS, Cairo JP, Lima DJ, Squina FM, Ruller R, Pradella JG (2013) Understanding the cellulolytic system of Trichoderma harzianum P49P11 and enhancing saccharification of pretreated sugarcane bagasse by supplementation with pectinase and a-L-arabinofuranosidase. Bioresor Technol 131:500-507 